241 VASOPRESSIN RELEASE IN THE LAMB FETUS. Fred G. Smith, Richard Weitzman, Jean Robillard, Allen Erenberg, an Delbert Fisher. Univ. of Iowa, Iowa C1ty and UCLAHarbor General Hospital, Torrance, Calif., Depts of Pediatrics
Arginine vasopressin (AVP) release was studied in 16 chronic Arginine vasopressin (AVP) release was studied in 16 chronic fetal preparations between 101 and 141 days gestation following
the infusion of $5 \%$ NaC1. The mean baseline plasma AVP in fetuses from $101-120(\mathrm{~N}=20)$ days was $1.90+0.46 \mu \mathrm{U} / \mathrm{ml}$ with a plasma osmolality of $292.9 \pm 1.75 \mathrm{mOsm} / \mathrm{kg}$. In fetuses 121 days to 141 days gestation, the mean baseline plasma AVP ( $N=11)$ was significantly lower $0.77 \pm 0.19 \mu \mathrm{U} / \mathrm{ml} \quad(\mathrm{P}=<0.05)$ whereas the plasma osmolality was simīlar to that in the younger fetuses $(292.7+$ $1.9 \mathrm{~m} 0 \mathrm{sm} / \mathrm{kg})$. The palred maternal baseline AVP concentrations 101 and 120 days gestation were significantly lower $(0.843+0.17$ $\mu \mathrm{U} / \mathrm{ml})$ than the mean fetal levels $(1.59 \pm 0.44 \mu \mathrm{U} / \mathrm{ml})$ however fetal and maternal levels between $121-14 \overline{1}$ days were similar; 0.68 $\pm 0.27 \mu \mathrm{U} / \mathrm{ml}$ and $0.70 \pm 0.22 \mu \mathrm{U} / \mathrm{ml}$ respectively. A 1 inear regression of the logarithum of baseline plasma AVP and plasma osmolality in 30 fetuses showed a significant correlation $(P-<0.001, r=0.62)$. Plasma AVP was elevated after $5 \%$ NaCl infusion in 16 of 19 experiments. Studies of the relationship between steady state plasma AVP and plasma osmolality in adult sheep show a slightly flatter slope (adult 0.0282, fetal 0.0395). This observation suggests that the fetal osmoreceptors are more responsive to changes in tonicity than the adult sheep. Furthermore, the response to $5 \% \mathrm{NaCl}$ as measured by the difference in the log plasma AVP divided by the difference in plasma osmolality was greater in the fetus.

\section{THE NATURE AND SIGNIFICANCE OF AMNIOTIC FLUID (AF)} GLUCAGON. Mark A. Sperling, Ronald A. Christensen, tment of Pedatrics and obstetrics, Torrance, Calif. tal, Department fified immunoreactive glucagon (IRG) measured by "We have identified immunoreactive glucagon (IRG) measured by "specific" radioimmunoassay, in AF collected during the first
$10-20 \mathrm{~W}$ for genetic screening or third trimester (30-40 W) for 10-20 W for genetic screening or third trimester (30-40 W) for $38 \mathrm{pg} / \mathrm{ml}$ (mean \pm SEM) was significantly greater than in the first $10-20 \mathrm{~W} ; 43 \pm 10 \mathrm{pg} / \mathrm{ml}(\mathrm{p}<0.05)$. However no correlation was discerned between third trimester AF-IRS and type of pregnancy or course of neonatal glucose homeostasis in normal, premature, or infants of diabetic mothers (IDM), al though spontaneous glucagon secretion following birth is obtunded in IDM. To investigate the nature of AF-IRG, selected samples were chromotographed on Biogel P10 columns calibrated with blue dextran, $125 \mathrm{I}-$ insulin. 125I-glucagon and 125I, and IRG determined in all eluate fractions. Large peaks of IRG eluted with the void volume (MW > 20000 ) or in the region ahead of insulin corresponding to a MW of approximately 9000 . A 3-fold concentration of AF was required to demonstrate a small IRG peak corresponding to its appropriate marker ( $3500 \mathrm{MW})$. Addition of crystalline glucagon to AF resulted in an elution profile corresponding to its appropriate
$3500 \mathrm{MW}$ position. Conclusion: Amniotic fluid IRG appears to 3500 MW position. Conclusion: Amniotic fluid IRG appears to
reflect increasing gestational maturation, but fails to predict neonatal glucose homeostasis. This fallure may be related to the nature of amniotic fluid IRG; "pro" or "big" glucagon rather than biologically active $3500 \mathrm{MW}$ material. CHARACTERISTICS OF VASOPRESSIN (AVP) RELEASE DUR-
$\mathbf{2 4 3}$ ING ADRENOCORTICOAROPHEN (ACCH) INDUCED PARTURITION IN THE LAMB. Raymond Stark, Kazim Hussain, Salha Daniel, Jacques Milliez, Hisayo Morishima, L. Stanley James, Div. of Perinatal Med., Coll. of $P$ \& S., Columbia Univ.., N. Y.

During premature parturition induced by ACTH there is a rise in fetal AVP only after the onset of labor. Fetal AVP levels which peak at delivery are not related to maternal levels which rise only during pushing. To investigate the characteristics of AVP release as measured by radioimmunoassay, 9 fetal lambs were instrumented at 121 days gestation. At 129 days, 7 fetuses were infused at $1.5 \mathrm{ml} / \mathrm{hr}$ with ACTH $(10 \mathrm{mg} / \mathrm{kg} / \mathrm{hr})$ and 2 with saline. Delivery occurred after a mean of 74 hours of ACTH infusion. During infusion fetal $\mathrm{pH}(7.36 \pm .002 \mathrm{~S} . \mathrm{E}$.$) and \mathrm{pCO}_{2}(42+2 \mathrm{mmHg})$
remained constant while $\mathrm{PO} 2$ decreased $(22+2$ to $18+2 \mathrm{mmHg}, r=.96)$. Serum electrolytes and osmolarity remained stable through infusion and early labor $(\mathrm{Cl} 109.5+1.5 \mathrm{meq} /, \mathrm{Na} 145+1.3 \mathrm{meq} /, K 4.0+.45 \mathrm{meq} /$ and osmolarity $289+3.2 \mathrm{mOsm} / \mathrm{L}$ ). Fetal AVP rose from prelabor mean values of $1.8+1.8 \mathrm{pg} / \mathrm{ml}$ to $40+73 \mathrm{pg} / \mathrm{ml}$ in active labor, $173+404 \mathrm{pg} /$ $\mathrm{ml}$ in the pushing phase and $720 \mp 1470 \mathrm{pg} / \mathrm{ml}$ at delivery, then decreased 30 minutes after delivery to $360 \mp 340 \mathrm{pg} / \mathrm{ml}$. During labor serial fetal arterial AVP levels were compatible with pulsatile release unrelated to uterine contractions. In ACTH induced parturition the AVP rise is not related to the initiation of labor or changes in serum osmolarity but may be related to changes in fetal oxygenation. We speculate that the high levels of AVP may be instrumental in fetal cardiovascular adjustments to the stress of labor.
244 ISYCHOI OGICAI DEVETOPNEITT OF CHIIDREN VITH $X$ AND $Y$ CIPCCIOSONF, ANEII LOIDY. Dom.Stewart, J.D. BAliry, Hospltal for S1ck Chlldren, Toronto, Ontario

Thirty-three rhiddren f'entified at birth as havsng aneurlolidy of ser chromosomas were assessed $v 1$ th one to four annua examinations between four and eight years of age for general intelligenrn, verbal skills, perceptual functioning, motor ability, and educational attainmont. Interviews, rating scales and symptomatic check lists provided information on temperamental character istics of the chlldren and also of parental attitudes. The psycholog!cal assessments vife done "blind" and in the case of the rated variahles, the use of two judges provided a basis for det.urinining rellability of the raters. Findings follow in this tab!r. (alj units are standard scores)

\section{IEAN SCORES FOR SEPARATE PSYCHOLOGICAL VARIABLES}

\begin{tabular}{|c|c|c|c|c|c|}
\hline$\frac{\text { Karyotyze }}{A ? \times X Y}$ & $\frac{n}{2 n}$ & $\frac{\text { Verbal }}{8 \sqrt{.04}}$ & $\frac{\text { Fraceptual }}{3 r, 9}$ & $\frac{\text { Muant Itat Ive }}{84.6}$ & $\begin{array}{l}\text { liemory } \\
86.8\end{array}$ \\
\hline $17 \mathrm{XYY}$ & द & 81.0 & 07.2 & 85.5 & 8.3 .8 \\
\hline $47 \mathrm{xXX}$ & $?$ & $7 ? .0$ & $20 . ?$ & 86.0 & 81.3 \\
\hline
\end{tabular}

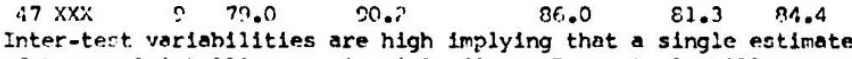
of "gennral inteligence" is mis eading. Perceptual skilis generall: fall "ithin average limits wile verbal ability is lo\%。 Deficits are most pronounced in $47 \mathrm{XXX}$ children. Temperamenta difficulties or overt behaviour problems have been encountered in all grouns. The oroups, thus far, co not differ in the incidence of behaviour irobiems nor do particular constellations of behavloural traits characterize any karyotype.

24 HUMAN AMNIOTIC MEMBRANE: A SOURCE OF ACTIVE FETAL GLUCOCORTICOIDS? A. Keith Tanswell, D. Worthington, Barry T. Smith (Spon. by H.W. Taeusch) Queen's Univ. Dept.Paediatrics, Kingston, Ont.

We have recently shown that in both sheep and human pregnancies the ratio of the active glucocorticoid, cortisol (F), to its inactive 11-oxidized form, cortisone (E), in amniotic fluid increases with gestational age and is closely linked to lung maturation.

Samples (100 mg) of human amniotic membrane were obtained within 3 hours of delivery and incubated in the presence of equimolar amounts of $\mathrm{H}-\mathrm{F}$ and $\mathrm{C}-\mathrm{E}$. and $E$ were isolated and their content of "C and allowed the calculation of $8 F+E$ and $8 E \rightarrow F$ conversion. $8 F \rightarrow E$ (inactivation) was arbitrarily given a negative
value and the two results arithmetically summed to give the "C-11 activation index", a measure of the net gain (or loss) of glucocorticoid activity. We found that this index increases with gestational age ( $n=28$, slope $=0.671, r=0.674, p<.001)$, becoming positive at 30 weeks, and reaching values of 40-508 by term.

since glucocorticoid introduced into the amniotic fluid reaches the fetal circulation, the amniotic membrane activity is a potential source of active glucocorticoid for the fetus. Further studies will be necessary to determine if the observed activity is related to lung maturity.

(Supported by the M.R.C. of Canada)

46 INCREASES IN BRAIN GLUCOSB AND PLASMA GLUCOSE,

246 GLYCEROL AND B-HYDROXYBUTYRATE AFTER AMINOPHYLLINE. Jean Holowach Thurston, R1chard E. Hauhart, and John A. Dirgo. Dept. Pediat. Effects of aminophylline ( $100 \mathrm{mg} / \mathrm{kg} \mathrm{1.p.)}$ on brain carbohydrate and energy metabolism were studied in 2 11tters of normal 17-23-day-old mice (11 anima1s). Although no clinical effects were seen, $20 \mathrm{mIn}$ af ter aminophylline plasma glucose increased $22 \%(11.79 \pm 0.15$ v8 $8.90 \pm 0.80 \mathrm{~m} M$ in controls, $P=0.025)$; plasma $B$-hydroxybutyrate was $242 \%$ of control $(443 \pm 75 \mu M$ v8 $183 \pm 28, p=0.031$ ) and plasma glycerol, $258 \%$ of control (570 \pm

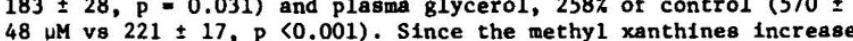
tissue cyclic AMP levels and/or catecholamine and glucagon release, these findings may reflect this action (Increased hepatic glucose output and 11polysis).

Brain cyclic AMP 1ncreased $56 \%, p=0.014$. Brain glucose increased dramatically, $1.47 \pm 0.12$ vs $0.76 \pm 0.08 \mathrm{mmol} / \mathrm{kg}$ in controls, $p=0.001$. Brain ATP, P-creatine, glycogen and lactate levels were unchanged. In the face of an apparentiy normal cerebral metabolic rate, the increased brain to plasma glucose concentration ratio, $0.13 \pm 0.01$ v8 $0.09 \pm 0.01$ in controls, $p=0.048$, suggests increased brain glucose transport.

B-hydroxybutyrate is a major metabolic fuel of the brains of young animals and glycerol is an ef fective substrate for hepatic gluconeogenes18; furthermore, in anoxic brain, glucose is the only source of ATP. In view of these facts, the findings presented in this report may explain the mechanisms(s) of the beneficial action of methyl xanthines in apnea of prematurity. 